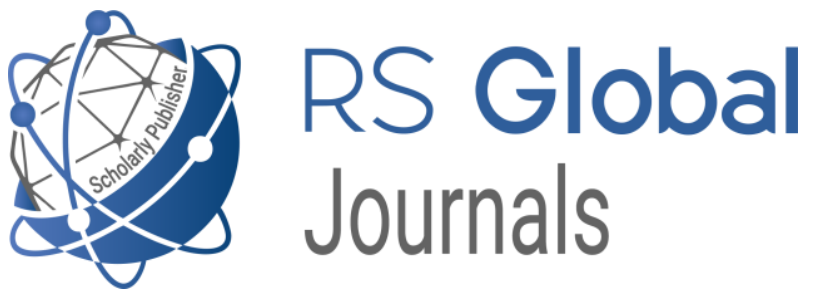

Scholarly Publisher

RS Global Sp. z O.O.

ISNI: 0000000484952390

Dolna 17, Warsaw, Poland 00-773

Tel: +48226022703

Email: editorial_office@rsglobal.pl

JOURNAL International Journal of Innovative Technologies in Social Science

p-ISSN

2544-9338

e-ISSN

2544-9435

PUBLISHER

RS Global Sp. z O.O., Poland

ARTICLE TITLE

СУЧАСНІ ТЕХНОЛОГІЇ ТА СТРАТЕГІЇ В ОНЛАЙН ВИКЛАДАННІ АНГЛІЙСЬКОЇ МОВИ ДЛЯ ГУМАНІТАРНИХ ФАКУЛЬТЕТІВ

$\operatorname{AUTHOR}(\mathbf{S})$

Чернишова С. О., Токменко О. П., Сидоренко О. А.

Svitlana O. Chernyshova, Olena P. Tokmenko, Olena A.

Sydorenko. (2021) Suchasni Tekhnolohii ta Stratehii v Onlain

ARTICLE INFO Vykladanni Anhliiskoi Movy Dlia Humanitarnykh Fakultetiv. International Journal of Innovative Technologies in Social Science. 3(31). doi: 10.31435/rsglobal_ijitss/30092021/7678

DOI https://doi.org/10.31435/rsglobal_ijitss/30092021/7678

RECEIVED

06 August 2021

ACCEPTED

10 September 2021

PUBLISHED

14 September 2021

LICENSE

This work is licensed under a Creative Commons Attribution

4.0 International License.

(C) The author(s) 2021. This publication is an open access article. 


\title{
СУЧАСНІ ТЕХНОЛОГЇ̈ ТА СТРАТЕГІЇ В ОНЛАЙН ВИКЛАДАННІ АНГЛІЙСЬКОЇ МОВИ ДЛЯ ГУМАНІТАРНИХ ФАКУЛЬТЕТІВ
}

\author{
Чернишова С. О., к. філол. н, дочент кафедри іноземних мов історичного та філософського \\ факультетів Інституту філології Київського наџіонального університету імені Тараса \\ Шевченка, ORCID ID: https://orcid.org/0000-0003-0284-2001 \\ Токменко О. П., к. пед. н, дочент кафедри іноземних мов історичного та філософського \\ факультетів Інституту філології Київського національного університету імені Тараса \\ Шевченка, ORCID ID: https://orcid.org/ 0000-0003-2824-3218 \\ Сидоренко О. А., к. філол. н, доцент кафедри іноземних мов історичного та філософського \\ факультетів Інституту філології Київського начіонального університету імені Тараса \\ Шевченка, ORCID ID: https://orcid.org/ 0000-0001-9794-9754
}

DOI: https://doi.org/10.31435/rsglobal_ijitss/30092021/7678

\section{ARTICLE INFO}

Received 06 August 2021

Accepted 10 September 2021

Published 14 September 2021

\section{KEYWORDS}

online learning, online learning methodology, synchronous online learning, asynchronous online learning, teaching English online.

\begin{abstract}
The article is devoted to the use of online technologies and strategies in learning a foreign language.

In particular, in close correlation with full-time education, the article considers the leading strategies and technologies used by higher education institutions in building online foreign language courses. These are mainly lectures, discussions, games, simulations, blog technologies, wiki technologies, etc.

The article mentions the work of the world's leading online universities. Quotes from their supervisors and lecturers are given, which analyze the main concepts that distinguish or, conversely, resemble online and offline learning.

We can say that today the technology has reached a sufficient level for students to receive a proper education, even in distance learning. Even more, thanks to the synchronous and asynchronous method of teaching, students get additional opportunities that are not always available in the classroom.

However, it is worth noting that mastering, selecting and successfully using existing technologies is another challenge for teachers working online.
\end{abstract}

The article also discusses the advantages and disadvantages that accompany online learning.

The article analyzes the methods and means of learning a foreign language online. According to the author of the article, the number of online courses, online faculties and online universities will grow steadily every year. Because they do not require significant investment and allow people to be educated regardless of their geographical location. However, online education relies heavily on traditional education, it creates space for the preservation, development and improvement of traditional learning models, as well as selectivity in choosing more effective methods.

Citation: Svitlana O. Chernyshova, Olena P. Tokmenko, Olena A. Sydorenko. (2021) Suchasni Tekhnolohii ta Stratehii v Onlain Vykladanni Anhliiskoi Movy Dlia Humanitarnykh Fakultetiv. International Journal of Innovative Technologies in Social Science. 3(31). doi: 10.31435/rsglobal_ijitss/30092021/7678

Copyright: (C) 2021 Svitlana O. Chernyshova, Olena P. Tokmenko, Olena A. Sydorenko. This is an open-access article distributed under the terms of the Creative Commons Attribution License (CC BY). The use, distribution or reproduction in other forums is permitted, provided the original author(s) or licensor are credited and that the original publication in this journal is cited, in accordance with accepted academic practice. No use, distribution or reproduction is permitted which does not comply with these terms.

Постановка проблеми у загальному вигляді та її зв'язок 3 важливими науковими чи практичними завданнями.

Упродовж останніх двох років термін «онлайн навчання» міцно увійшло в лексикон української освіти, адже завдяки поширенню епідемії значний відсоток школярів та студентів навчається онлайн. 
Сьогодні лунає безліч критичних зауважень і від викладачів, і від вчителів, і від учнів та студентів. Адже, відверто кажучи, українська освітня система не була готова до повного чи часткового переходу в режим онлайн. I тому було безліч причин: від банальної, коли викладачі не мали комп'ютерів чи не вміли ними користуватися, до відсутності методологічних напрацювань викладання.

Хоча варто відзначити, що завдяки розвитку інтернет технологій, якісна освіта стала більш доступною широкій громадськості. I йдеться як про академічну, так і про ділову освіту. Сьогодні більшість університетів світу пропонують дистанційне онлайн навчання, розвиток якого прискорила пандемія, що в деяких випадках зробила цей вид навчання єдино прийнятним. Цілком можливо, що вже у найближчій перспективі онлайн навчання може витіснити, чи суттєво потіснити традиційні методи здобуття освіти. І тому є безліч причин.

Аналіз останніх досліджень і публікацій 3 даної теми, виділення невирішених раніше частин загальної проблеми, котрим присвячусться означена стаття.

Останнім часом у науковій методичній літературі з'явився цілий корпус досліджень, присвячених використанню технологій інтернету першого покоління (Веб 1.0) i інтернету другого покоління (Веб 2.0) у формуванні всіх аспектів іншомовної комунікативної компетенції.

Головним чином ці розробки стосувалися таких методик: навчання писемного мовлення за допомогою електронної поштової групи; вікі- технології; блог-технології; навчання говорінню і аудіювання за допомогою навчальних подкастів тощо.

Перші наукові розробки використання інтернет-технологій у вивченні іноземної мови датуються початком XX століття і від тоді кількість засобів інтернет-комунікації невпинно зростає.

Для України онлайн навчання стало вимушеним заходом, тоді як у США та країнах Євросоюзу вже існують цілі онлайн університети, які цілком здатні надавати якісну освіту, без відвідувань студентами аудиторій.

Так американський дослідник Джаред Стейн радить при підготовці занять, які відбуватимуться у онлайн режимі, надати пріоритет навчальним цілям перед технологіями. «Починайте $з$ чітким розумінням, якого результату ви хочете досягти: що ви хочете, щоб учні засвоїли в кінці курсу. Плануючи програму, завжди опирайтеся на цілі, а не на технології. Хай ціль, обирає технологію, за допомогою якої ви її втілите, а не навпаки» ${ }^{1}$. Тож лише після того, як викладачі визначать, чого вони хочуть навчити, і якими методами вони можуть це зробити, варто переглянути доступні їм технології навчання в Інтернеті та визначити ті, які найкраще доповнятьці цілі. I Джаред Стейн не випадково наголошує на цьому, адже інтернет дає нам безліч можливостей і у викладача досить часто існує спокуса перебрати із засобами, або перекласти частину своєї роботи на технології.

На противагу думці Джареда Стейна, доктор Сюзен Олдрідж, президент Університету Дрекселя, впевнена, що сьогодні існує достатній набір технологій віртуального навчання, який дає змогу відтворити онлайновим закладам навчальний досвід, що буде рівноцінний досвіду здобутому в аудиторіях. Так Сьюзен Олдрідж наголошує, що «... багато в чому онлайннавчання схоже на навчання за партами. Наші віртуальні студенти навчаються за тією ж навчальною програмою, навчаються на тому ж факультеті $і$ здають ті ж завдання, ш⿻о $і$ їх однолітки на стаціонарі. Вони просто здобувають дипломи на відстані у віртуальній аудиторії, а не у фізичній, і спілкуються зі своїми викладачами та однокурсниками за допомогою сучасних чудес технологій»»².

Ще один дослідник онлайн-навчання Доктор Джеймс Гроувс, доцент інженерного факультету Університету Вірджинії звертає увагу на схожі та відмінні риси у двох способів навчання. Джеймс Гроувс переконаний, що і інтернет, і стаціонар може використовувати один і той самий спосіб, а саме синхронне навчання у яке будуть залучені усі студенти та викладач одночасно. В інтернеті це можна робити завдяки таким програма як скайп, zoom, hangouts, де всі учасники заняття бачать один одного і можуть будь-якої миті долучитися до дискусії. На думку Джеймса Гроувса цей процес дуже подібний до процесу організації навчання в аудиторії, але тут дуже важливо, яку саме стратегію обере викладач, при плануванні онлайн курсів. Саме тут технологія

\footnotetext{
${ }^{1}$ Interview with Jared Stein, VP of Research and Education at Canvas by Instructure Retrieved from https://www.onlineeducation.com/expert-interviews/jared-stein-canvas-instructure

${ }^{2}$ Interview with Dr. Susan Aldridge, President of Drexel University Online and Sr. VP of Online Learning at Drexel University. Retrieved from https://www.onlineeducation.com/expert-interviews/susan-aldridge-drexel-university
} 
має вирішальне значення. «Ми вважаємо, що ключовим елементом освіти є інтелектуальне залучення студентів до інших учасників навчального процесу - викладачів факультету, асистентів $і$ однокурсників. Відвідування аудиторій дає можливість змішувати студентів, і ми бачимо великі перспективи цього змішування, оскільки вони йдуть на користь усім студентам» ${ }^{1}$. Так на думку Джеймса Гроувса такого ефекту можна досягнути і у викладанні онлайн, головне підібрати правильні технології, які дозволять залучити усіх студентів до взаємодії з усіма суб'єктами.

Головним чином, для досягнення синхронної методики викладання, дуже важливо, як саме передається вміст викладеного матеріалу.

Викладачі, які працюють з великими аудиторіями повинні продумати як залучити усіх студентів: на аудіо чи на відео зробити головні акценти; чи треба додати письмовий чат для обговорення чи двосторонній аудіо контакт; чи варто додати додаткові слайди та іншу графічну інформацію тощо. Коли мова йде про менші класи, система організації може бути простішою, але вона також має бути достатньою продуманою, щоб навчальний процес був максимально наближеним до аудиторного.

Викладачі, які викладають синхронні курси, не повинні обмежуватися лише методом доставки контенту: вони можуть поєднувати їх 3 додатковими технологіями, щоб пристосуватися до ширшого кола слухачів.

\section{Наприклад це можуть бути:}

- Потокові відеоплатформи;

- Чати в режимі реального часу, окремо або на курсах;

- Інструменти веб-конференцій;

- Доступність телефону;

- Віртуальний графік роботи;

Кожен із цих інструментів заохочує активну участь та взаємодію усіх учасників навчального процесу. На основі таких занять досить часто викладачі роблять відео лекції, що дає основу вибудові асинхронного онлайн навчання. Де студенти, які пропустили заняття, можуть надолужити матеріал у зручний для себе час. Проте суто асинхронні курси значною мірою спираються саме на такі матеріали.

Асинхронні курси - це одна 3 переваги онлайн освіти. Онлайн курси, які дозволяють студентам переглядати лекції, отримувати доступ до матеріалів та співпрацювати 3 викладачами та однолітками за власним розкладом, називаються асинхронними курсами. Ці методи навчання дозволяють учням переглядати та переглядати уроки за необхідності. Ці варіанти можуть бути дуже корисними для студентів, які не можуть відвідувати заплановані сесії, сподіваються мінімізувати групові проекти, обговорення в прямому ефірі або хочуть працювати на уроках у власному темпі.

Програми, які використовують асинхронні методи доставки контенту, вимагають іншого підходу до навчання - такого, який сильно залежить від використовуваних технологій. Як і при синхронних інструкціях, такі характеристики, як розмір класу та уподобання інструктора, можуть впливати на те, які інструменти використовуються в асинхронних онлайн класах.

Здебільшого асинхронна методологія передбачає:

- Попередньо записані лекції, які можна завантажити;

- Презентації Microsoft PowerPoint $з$ голосовою передачею або без неї;

- Форуми та дошки обговорень;

- Спілкування електронною поштою;

- Диск Google та подібні інструменти для спільної роботи;

- Інструменти для роботи в неробочий час, наприклад віртуальні навчальні центри та віртуальні ресурсні центри;

- Тощо.

Таким чином, ми можемо говорити, що онлайн навчання усе активніше впроваджується у освітні програми провідних вузів світу, які, опираючись на освітню методологію офлайнових методик, випрацьовують нові, що притаманні лише онлайн формі навчання.

\footnotetext{
${ }^{1}$ Interview with Dr. James F. Groves, Associate Professor, University of Virginia School of Engineering and Applied Science. Retrieved from https://www.onlineeducation.com/expert-interviews/james-groves-university-of-virginia
} 
Мета. Метою статті $є$ теоретична розробка методики використання онлайн технологій для формування мовного, мовленнєвого та соціокультурного компонентів комунікативної компетенції студентів при вивченні іноземної мови в гуманітарних ВНЗ.

Виклад основного матеріалу.

Говорячи про використання онлайн технологій при вивченні іноземних мов, варто відзначити, що цей спосіб не є новим навіть для України. Уже понад десять років, провідні школи 3 вивчення іноземних мов проводять частину чи повний курс занять в режимі онлайн. I це не дивно, адже інтернет дає безліч можливостей для вивчення іноземних мов. Частина таких курсів, як наприклад курс розроблений телеканалом ВВС ще у 2013 році, базується винятково на асинхронному способі навчання, яке відбувається без залучення інструктора у зручний для студентів час, із зручною для них інтенсивністю засвоєння.

Серед головних факторів, що сприяли розвитку вивчення іноземних мов у режимі онлайн - можна виокремити такі:

- потреба навчатися упродовж усього життя;

- розвиток інтернет технологій;

- створення необхідної кількості засобів комунікації (таких як facebook, zoom, youtube, hangouts тощо);

- поширення інтернет покриття на більшій частині території;

- покращення пропускної здатності інтернету;

- масове використання комп’ютерів ноутбуків та інших гаджетів, що уможливлюють комунікацію з викладачем;

- також адаптивний характер технологій.

Американські дослідники Девід Годшалк та Лінда Лейсі визначають чотири каталізатори, що здатні вплинути на засвоєння онлайн-навчання:

1) зміна поколінь;

2) розробка та підтримка так званої програми «виживання»;

3) інституційна відповідність;

4) розвинута практика попиту ${ }^{1}$.

Автори у своєму дослідженні впливу технологій на планування дистанційного навчання роблять висновок, що нам слід застосовувати технології для вдосконалення планування освіти.

Також дослідники наголошують, що онлайн-навчання не має власної основи викладання, воно так само спирається на традиційне навчання 3 похибкою на підбір необхідних інструментів. У традиційному навчанні потрібні три компетенції: професійна, методична та психопедагогічна грамотності, що базуються на технологічній компетенції.

Онлайн-програми навчання спрямовані на передачу тих самих знань та навичок, що й на стаціонарі, тому викладачі адаптують ті ж методи навчання до середовища онлайн-навчання. У одних випадках доставка інформації є єдиною помітною відмінністю, тоді як в інших технологія докорінно змінює або збагачує навчальний процес. Доктор Олдрідж наголошує, що «Викладачі, які викладають у віртуальному просторі, також дуже добре усвідомлюють необхідність створення викладацької присутності, яка полегшує та спрямовує навчальний процес таким чином, щоб залучати студентів до активного та достовірного, вимірюваного та індивідуального досвіду навчання, так у деяких програмах ми впроваджуємо віртуальну реальність за допомогою складних моделювань та ігор, які забезпечують безпечне, але складне середовище для залучення студентів до справжньої проблемної діяльності та рольових вправ, спрямованих на розвиток навичок, необхідних їм, щоб стати успішними практиками»².

Онлайн освіта дуже подібна до стаціонарної, з різницею в тому, що технологічні компетенції повинні бути на вищому рівні, ніж зазвичай (оцінка та підготовка організаційної готовності; розробка відповідного змісту; розробка відповідних презентацій; впровадження електронного навчання).

Професор Бойччер (Boettcher) виокремлює такі принципи онлайн-навчання:

- присутність на платформах, що надають послуги викладання;

\footnotetext{
${ }^{1}$ Evans, J. R., \& Haase, I. M. (2011). Online business in the twenty-first century: An analysis of potential target markets. Internet Research: Electronic Networking Applications Policy 11(3), 246-260.

${ }^{2}$ Interview with Dr. Susan Aldridge, President of Drexel University Online and Sr. VP of Online Learning at Drexel University. Retrieved from https://www.onlineeducation.com/expert-interviews/susan-aldridge-drexel-university
} 
- наявність стимулюючого середовища для інтернет-спільноти;

- чіткі та зрозумілі критерії навчання (як спілкуватися, скільки часу вони витратять на робочий день, якою буде система оцінювання тощо);

- використання різних груп(групові заняття, парні, індивідуальні лекції тощо);

- вкраплення неформального спілкування (запитати як справи, чи $є$ якісь пропозиції, щодо навчання, які існують проблему у засвоєнні матеріалу тощо)

- живе спілкування у форматі - питання - обговорення;

- використання презентацій, сайтів, хостингів, до яких мають доступ як викладач, так i студент (вікіпедія, фейсбук, ютуб, зум тощо) ${ }^{1}$;

Варто зауважити, що оналайн-викладання англійської мови стає усе більш популярним як у світі, так і в Україні. Серед головних переваг онлайн навчання фахівці виокремлюють:

- ширший доступ до освіти серед потенційних учнів;

- здешевлення процесу навчання;

- гнучкість графіку;

- широкий діапазон засобів навчання та перевірки знань.

Сьогодні виокремлюють 4 основні методики викладання англійської мови:

1. Grammar Translation - класична методика по вивченню англійської мови.

Говорячи про цей метод, основною характеристикою якого $є$ вивчення граматичних правил та їх застосування під час перекладу, варто зауважити, що в онлайн навчанні він зазнав суттєвих змін. Так на зміну класичним для офлайну засобам - прийшли інші способи, такі як перегляд дитячих передач, фільмів з субтитрами, фільмів без субтитрів, новин, кліпів, живий діалог, написання статей в вікіпедії, ведення блогу, ведення онлайн обговорень у соціальних мережах тощо.

\section{Direct Method - прямий або природний метод.}

Цей метод передбачає здобуття студентом правильної вимови, при цьому методі мало уваги приділяється аналізу граматики. Сьогодні інтернет надає величезні можливості для використання цього методу для дистанційного навчання англійської мови. Зокрема, за допомогою, вебінарів, конференцій, створення відео, спілкування у відеочатах тощо.

\section{Audio-lingualism - один 3 перших сучасних методів.}

Audio-lingualism - це метод повторення і запам'ятовування стандартних фраз. В онлайн навчанні існує низка сайтів, які спрямовані на цей метод, де можна вивчити різні аспекти англійської мови, потренуватися у використанні і запам'ятовуванні окремих слів, фраз синтенцій. На відміну від офлайну - онлайн дає тут масу переваг, адже проходити навчання за таким методом можна у будь-який час, головне, щоб під рукою був смартфон та доступ до інтернету.

\section{Communicative Language Teaching - сучасний стандартний метод. ${ }^{2}$}

Четвертий метод - це метод вивчення іноземної мови у діалозі. Головним завданням викладача $-\epsilon$ організація спілкування між різними учасниками групи. Для цього методу перевага надається малим групам чи індивідуальним заняттям. Сам процес навчання може відбуватися через будь-які існуючи сервіси, такі як скайп, зум, фейсбук тощо.

Кожна 3 цих чотирьох методик у той чи інший спосіб залучає різні стратегії. Насамперед йдеться про: лекції, обговорення, демонстрації, моделювання, гра тощо.

Лекції - одна 3 найбільш поширених стратегій навчання. Яка використовується як в онлайн навчанні, так і в офлайн. Так само, як і в аудиторії, більшість викладачів, що працюють онлайн використовують лекції для передачі інформації, сприяння розумінню та розпалювання інтересів студентів. Однак варто пам'ятати, що лекції ставлять студентів у пасивну роль, що може негативно вплинути на їх залученні до навчального процесу в інтернеті. Тож можемо наголосити, що при плануванні онлайн занять, варто використовувати лекції разом з більш активними навчальними стратегіями, що будуть більшою мірою залучати студентів до навчального процесу.

Обговорення може бути чудовим доповненням до лекції, однак може використовуватися і як окрема навчальна вправа. Чи варто говорити, що обговорення

\footnotetext{
${ }^{1}$ Boettcher, J. V. (February 16, 2019). Ten Core Principles for Designing Effective Learning Environments: Insights from Brain Research and Pedagogical Theory. Preuzeto sa: www.innovateonline.info/index.php?view=article\&id=54.

${ }^{2}$ Minela Kerla Methods and Techniques in Online English Language Teaching Conference: 7th International Conference on Education and New Learning Technologies. Barcelona (Spain). 6th-8th of July, 2015. http://iated.org/edulearn
} 
підтримує навчання та активно залучає студентів до навчального процесу. Студенти мають можливість ставити питання та передавати свої ідеї під час відпрацювання аналітичних та пізнавальних навичок. До того ж, на думку Кеннета Чепмена, віце-президента 3 ринкової стратегії компанії «DistanceLearn», більшості студентів зручніше брати участь в онлайн дискусіях, ніж у дискусіях, що відбуваються онлайн. «Здатність брати участь у безпечному середовищі також є однією з ознак онлайн навчання. Не всі студенти мають впевненість (або мовні навички) вільно висловлюватись у традиційних умовах» ${ }^{1}$.

На синхронних курсах професори ставлять запитання та обговорюють матеріал курсу за допомогою чатів у реальному часі та інструментів для веб-конференцій. Учні, які навчаються асинхронним способом, мають можливість спілкуватися з одногрупниками та викладачами за допомогою форумів, соціальних мереж, відеохостингів тощо.

Демонстрація - дуже популярний вид навчальної стратегії, який так само поширений в онлайн навчанні, як і в традиційному. Демонстрації $є$ основою, коли йдеться про передачу певних концепцій та процесів. Вони також $є$ одними 3 методів навчання, розширених віртуальним навчальним середовищем. Сьогодні існує безліч програм, хостингів та сервісів, які забезпечують можливість надання демонстрації як синхронним, так і асинхронним способом. Причому демонстрація певної інформації може надходити не лише від викладача, а й від студентів. Особливо, коли йдеться про вивчення іноземної мови. Демонстрація, поруч із обговоренням - стають головними стратегіями онлайн викладання.

Моделювання - симулятори, реалізовані в реалістичному цифровому середовищі, дозволяють онлайн студентам дистанційно перевіряти практичні навички та знання. Здебільшого ця стратегія покликана для здобуття студентами певного досвіду, без страху зазнати поразки чи понести відповідальність. Здебільшого ця стратегія застосовується у медицині, біології, юриспруденції. Однак стратегія моделювання може бути застосована і в вивченні іноземних мов. Так студенти та викладач можуть моделювати ситуації, в яких опиниться студент і потребуватиме набору певних лексичних чи поведінкових знань. Це може бути від банальних побутових ситуацій, в які потрапляють туристи, до відвідувань журналістами гарячих точок тощо.

Ще однією інтернет стратегією, що може бути вдало застосована при вивченні іноземної мови студентами є гра.

Як і моделювання, ігри дозволяють студентам отримати практичний досвід у доступному цифровому середовищі. Вони також можуть збільшити участь студентів, оскільки учні можуть вважати їх більш захоплюючими та менш стресовими, ніж моделювання.

При правильному підході, ігри можуть стати головним рушієм прогресу в освоєнні іноземної мови студентами. Так викладачі можуть створювати таблиці лідерів та інші мотиваційні інструменти, щоб запровадити дружні змагання та, у свою чергу, спонукати студентів оволодіти необхідними знаннями та навичками.

\section{блог-технологію.}

Ще однією стратегією, яка притаманна винятково онлайн навчанню, можна вважати

Так на думку американського дослідника Стівена Доунса, однією 3 ключових технологій вивчення іноземної мови студентами є блог-технологія.

У своїй роботі Стівен Доунс виокремлює п'ять основних способів використання блогтехнології в навчанні:

1) вчителі використовують блог-технологію замість стандартної класної вебсторінки, на якій вони розміщують розклад курсу, домашнє завдання, тексти / статті для вивчення і вправи;

2) викладачі розміщують на класному блозі адреси сайтів в Інтернеті, які можуть використовуватися учнями для глибокої і ефективної підготовки з досліджуваної теми;

3) блог-технологія використовуються для організації дискусії, що дозволяє студентам i викладачам краще пізнати один одного, думки інших, виявити подібності та відмінності;

4) викладачі використовують блоги для організації класних семінарів i викладу прочитаного;

5) студентам пропонується створити власні блоги, в яких вони звітують про виконану роботу, тобто виконують вправи, пишуть есе, статті із запропонованих питань.

\footnotetext{
${ }^{1}$ Kenneth Chapman. (2019, July 21). Disrupting Learning Models: Using New Technology to Update Your Learning Program. Retrieved from https://www.hrexchangenetwork.com/events-clo-canada/speakers/kenneth-chapman
} 
Поступово, дослідники розширювали коло методичних завдань блогів. 3 розвитком методик навчання іноземної мови засобами навчального інтернет-блогу, збільшувалося коло аспектів, які обговорювалися в блогах. Так, наприклад, американські дослідники визначають блог як публічний щоденник, зв'язок між нами громадянами і нами особистостями. Вони вважають, що студенти можуть використовувати свої особисті блоги для широкого спектра письмових завдань, таких як:

- висловити свої враження від прочитаного;

- обговорити цікаві статті або записи, знайдені в мережі;

- ділитися особистими враженнями.

Таким чином можна виокремити такі переваги використання блог-технологій на заняттях з навчання писемного мовлення:

1) Студенти мають можливість миттєво відреагувати на прочитане повідомлення, наприклад, висловити співчуття іншій людині, підтримку, симпатію або антипатію. Для кожного виду листа їм необхідні різні мовні засоби і стилістичні прийоми.

2) Блоги можуть бути використані для створення проектів, причому студенти можуть помістити спочатку чернетки, і інші користувачі мережі можуть дати пораду, висловити свою думку щодо проекту.

3) У студентів підвищується рівень відповідальності за написане, оскільки їх записи доступні широкій аудиторії і як наслідок підвищується контроль граматики, синтаксису, вибору мовних засобів і стилістичних прийомів.

4) Студенти можуть використовувати записи один одного для висловлення власної думки, таким чином, думки не повторюються, що говорить на користь креативності мислення.

Варто наголосити, що дидактичні властивості і функції блог-технології дозволяють розвивати на її основі такі соціокультурні вміння:

- збирати, узагальнювати, класифікувати, систематизувати i інтерпретувати культурознавчу інформацію, використовуючи різноманітні джерела, включно з інтернетом;

- готувати культурознавчі матеріали, що відображають культурні та гострі соціальні аспекти культур країн, мову яких вивчають; матеріал;

- готувати матеріал використовуючи інтернет-ресурси, інтернет-ЗМІ, мультимедійний

- брати участь в дискусії мовою, що вивчається під час обговорення;

- вибирати соціокультурно-прийнятний стиль спілкування;

- розпізнавати і інтерпретувати соціокультурно-марковану лексику;

- виступати в якості представника своєї країни;

Однак, при всій сукупності переваг онлайн навчання, варто пам’ятати, що онлайн освіта вимагає періоду адаптації. Викладачі повинні вміти оцінювати ефективність навчального методу і відповідно адаптуватися до нього.

Так оцінюючи знання студентів, завжди варто робити акцент на стратегії навчання, яка була домінуючою у методології навчання. Сучасні системи управління навчанням можуть відстежувати прогрес і поведінку кожного окремого студента, а потім компілювати їх для огляду викладача. Дані, які називаються аналітикою навчання, розповідають викладачу, як часто студенти входять у систему, скільки часу вони витрачають на виконання кожного завдання та наскільки добре вони засвоюють матеріал. Навчальна аналітика допомагає викладачам швидко визначити проблемні сфери в будь-який момент, щоб вони могли відповідно скоригувати методи навчання, матеріали курси чи цілі.

Висновки. Таким чином можна констатувати, що використання дистанційних прийомів при вивченні іноземних мов широко застосовується у сучасній академічній та професійній освіті. Оскільки вона не потребує значних вкладень і дозволяє здобувати освіту людьми не залежно від їх географічного положення. Однак, онлайн-освіта значною мірою опирається на традиційну освіту, вона створює простір для збереження, розвитку та вдосконалення традиційних моделей навчання, а також вибірковості у виборі більш ефективних методів.

Пропоноване дослідження охопило сучасні стратегії онлайн навчання у вивченні іноземної мови з тісною кореляцією на навчання офлайн.

Цікавим видається дослідження стратегій та функціоналу, які використовуються в інтернеті і можуть бути залучені до навчального процесу. 


\section{ЛIТЕРАТУРА}

1. Interview with Jared Stein, VP of Research and Education at Canvas by Instructure. Retrieved from https://www.onlineeducation.com/expert-interviews/jared-stein-canvas-instructure

2. Interview with Dr. Susan Aldridge, President of Drexel University Online and Sr. VP of Online Learning at Drexel University. Retrieved from https://www.onlineeducation.com/expert-interviews/susan-aldridgedrexel-university

3. Interview with Dr. James F. Groves, Associate Professor, University of Virginia School of Engineering and Applied Science. Retrieved from https://www.onlineeducation.com/expert-interviews/james-grovesuniversity-of-virginia

4. Evans, J. R., \& Haase, I. M. (2011). Online business in the twenty-first century: An analysis of potential target markets. Internet Research: Electronic Networking Applications Policy 11(3), 246-260.

5. Boettcher, J. V. (February 16, 2019). Ten Core Principles for Designing Effective Learning Environments: Insights from Brain Research and Pedagogical Theory. Retrieved from www.innovateonline.info/index.php?view=article\&id=54.

6. Minela Kerla Methods and Techniques in Online English Language Teaching. Conference: 7th International Conference on Education and New Learning Technologies. Barcelona (Spain). 6th-8th of July, 2015. Retrieved from http://iated.org/edulearn

7. Kenneth Chapman. (2019, July 21). Disrupting Learning Models: Using New Technology to Update Your Learning Program. Retrieved from https:/www.hrexchangenetwork.com/events-clocanada/speakers/kenneth-chapman 